\title{
Implementation of Headmaster personality competence in developing competitive advantages: A Case Study in East Java, Indonesia
}

\author{
Nur Halima, Fitra Mardiana
}

Universitas wijaya putra, Indonesia

\begin{abstract}
The aim of this research is analyzing and describing about personality competence of principal in building school competitive advantage. This research approach uses qualitative approach to the type of case study research. Data collection techniques using in-depth interviews, participant observation, and documentation. The steps of data analysis consist of data collection, data reduction, data presentation, and drawing conclusions. Data validity checking techniques are carried out through credibility, dependability, confirmability, and data transferability. Based on research result, personality competence of principal in buliding school competitive advantage is carried out through these things : 1) Having good moral, developing traditions and culture of noble morals, and being a good role model for the community in a school/madrasah 2) Having strong personality integrity as a leader 3) Have the strong willing for selfdeveloping as principal /madrasah 4) Being open in carrying out the main and function 5) Controlling themselves in dealing with problems at work as a principal / madrasah. 6) Has the talent and interest in the position as an educational leader 7) Has a high spirit and a visionary and futuristic personality in an effort to build competitive advantage. As well as mastery of school principals on personality competencies that have a commitment to the Muhammadiyah organization for the development of educational institutions under the auspices of the Muhammadiyah foundation to become an institution of national pride.
\end{abstract}

Keywords-Personality Competence, Build Superiority.

\section{INTRODUCTION}

The headmaster is a central figure in enhancement of education quality in the school. The success or failure of an educational institution especially in the education unit is strongly influenced by the competency of the principal (the headmaster).

The Headmaster's competence as an education manager actually goes hand in hand with his ability in many ways, that ideally should be able to synergize management abilities and personality simultaneously. In this context it must be correctly understood that headmaster's role as a manager, as disclosed by Wahjosumidjo (2002, p. 90) are 1) the role of interpersonal relations, 2) the role of informational, 3) as a decision maker therefore a school principal must have a good and simultaneous personality.
The National Education Minister's decision No 045/U/2002 confirms that competency is a set of smart and responsible actions in carrying out tasks in accordance with certain jobs. While, Eriyanto $(2014$, p. 3) states that competence is knowledge, mastery, skills, attitude and values that are manifested in thinking, behaving and displayed through performance.

Other than that the result of research on SMKM 7 Gondanglegi Malang. According to researcher's observation this school has rapid progress in the academic and non-academic fields of the School which was founded in 1994. A few years ago, it was classified as a less developed suburban school. Even from year to year the number of enthusiasts has decreased. However, in a relatively short period of more or less five years, this school experienced very significant progress thanks to the influence of the principal's leadership. 
The achievements and reputations from at least 2013 to 2018, namely: (1) Leading trusted quality school from the 2015 global development foundation, (2) The best improvement vocational school from the image of Indonesia in 2015, (3) The best inspiring leader from Indonesia achievement center in 2015, (4) As the education and turoring program from the 2016 Indonesia awards center, (5) Reliable Indonesian educator from the Indonesia development service foundation in 2014 , (6) The best education and educator from Indonesia achievement awards in 2017, (7) Indonesian award of education from the award of human achievement in 2016, (8) Special award for international Islamic school robotic olympiad in Malaysia in 2017, (9) National reference vocational school from the Directorate of PSMK Kemendikbud RI in 2017, (10) Launching microbus Suryawangsa by the Ministry of Education and Culture Republic of Indonesia in 2017, (11) 1st place LKTI at the national level in the 2016 Olympics, (12) 3rd place in Olympic de robotics at the national level of the Republic of Indonesia Ministry of Research and Technology 2016, (13) Champion 3 PTK at the national level of Olympic in 2016, (14) The gold medal of the international Islamic schoolrobotic olympiad was conceived in 2016, (15) Special award at the international robotic olympiad school in Bandung in 2016, ( 16) 2013 ME Award general champion, (17) $2016 \mathrm{ME}$ awards indie film winner, (21) An energy award from the Ministry of Energy and Mineral Resources Republic of Indonesia in 2013, and (22) Tallent scounting of the best national school principals in 2013.

The focus of this research is the principal's managerial competence in building competitive advantage, with the following research question formulation: How is the implementation of the principal's personal competence on the side of his high spirit in building competitive advantage in SMKM 7 Gondanglegi Malang Regency? And how is the implementation of school principal's competence on the visionary and futuristic personality in an effort to build competitive advantage in SMK 7 Gondanglegi Malang?

\section{LITERATURE REVIEW}

\section{The headmaster Competency}

Competence is a noun which according to Powell (1997, p. 142) is interpreted as : 1) Skills, Abilities, 2) Authority. The adjective of competence is competent which means competent, capable, and agile. The understanding of competence is in principle the same as the understanding of competence according to Stephen Robbin (2008, p. 38) that competence is "the ability (ability) or capacity for someone to do various tasks in a job, where this ability is determined by 2 (two) factors, namely intellectual ability and physical ability.

The definition of competence as a skill or ability also put forward by Robert A. Roe (2001, p. 73) as follows : (1) Competence is defined as the ability to adequately perform a task, duty or role. (2) Competence integrates knowledge, skills, personal values and attitudes. (3) Competence builds on knowledge and skills and is acquired through work experience and learning by doing“. The competence can be described as an ability to carry out a role or task, the ability to integrate knowledge, skills, attitudes and personal values, and the ability to build knowledge and skills based on experience and learning which was done.

The definition of competence according to Becker and Ulrich (in Suparno, 2001, p. 24) that competency refers to an individual's knowledge, skill, ability or personality characteristics that directly influence job performance.

Based on the Minister of National Education Regulation No. 13 dated 17 April 2007 regarding the standard of school / madrasah principals, it is explained that the headmaster (principle) has to master about five dimensions of competence, namely, 1) Personality Competence, 2) Managerial Competence, 3) Entrepreneurship Competence, 4) Supervision Competence , 5) Social Competence.

Based on UU no. 20 National Education System and PP. No. 19 of 2005 related to articles governing the competency of school principals and referring to the decision of the Minister of National Education of the Republic of Indonesia Number 162/13/2003 concerning the assignment of teachers as school prin0cipals, article 9 paragraph (2), it is explained that aspects of the principal's assessment on the basis and responsibilities of the principal schools as, 1) leaders, 2) managers, 3) Educators, 4) Administrators, 5) Entrepreneurs, 6) Work climate creators, 7) Supervisors.

Allport, G.W. in his book "pattern and growth in personality", provides a very strong grand theory in the study of personality competencies. Personality competence according to Allport, G.W. (1961) include: 1) Sense of self extension. 2) A warm relationship with other people. 3) Self-acceptance. 4) Realistic views. 5) Self-objectification as well as insight and humor.

Gordon Allport (1961, p. 38) states that "personality is the dinamic organization within the individual of those psychophysical systems that determine his unique adjustment to his environtment". Literally, that definition can be interpreted that "personality is a dynamic 
organization in individuals about the psychophysical system which determines their unique adaptation to their environment".

Gorton \& Schneider (1991, p. 67) describe that personal competence as a set of ability and personal characteristic which reflect reality of attitude and behavior in execute their daily duties. The simpler definition is ability to be a role model. This example is a personal ability that reflects a steady, stable, mature, wise, and authoritative personality, so that and having good character.

Hoy \& Miskel (2005, p. 82) argue that personality competence must at least contain of knowledge of both social and religious customs, knowledge of culture and tradition, knowledge of the core of democracy, knowledge of aesthetics, appreciation and social awareness, correct attitude towards knowledge and work and be loyal to human dignity.

According to Greenberg \& Baron, (1995, p. 78) there are two factors that influence individual personality, namely heredity and environmental factors. There are 3 research about this personality and heredity factor. The first research toward genetic of children's temperament behavior, the second is a study of twins raised separately and a study of job satisfaction from time to time in various situations. Interestingly research on twins suggests that the caring environment does not significantly affect the personality development of the twins.

The dimension of personality competence in Permendiknas No. 13 of 2007 consists of six competency dimensions:

1. Having good morals, developing a culture and tradition of noble morals, and being a role model of noble morals for the community in schools / madrasah.

2. Having strong personality integrity as a leader

3. Having strong willingness in self-development as headmaster/ principle of madrasah.

4. Be open in carrying out the principal and functions.

5. Self-controlling in dealing with problems at work as a principal/madrasah.

6. Having the talent and interest in the position as an educational leader.

In relation to the role of personality competence in developing competitive advantages in schools, Schneider (1996, p. 695-705) in his research finds that personal attribute that are the same as the values of the organization will support schools to become superior or more qualified schools, then Miron (2004, p. 80) describes that personal characteristic that engage as a leader competence influence to innovation ability, quality of operations, and efficiency as well as ways of interacting with organizational cultural values that will have an impact on increasing the achievement of organizational goals.

\section{Competitive Advantage}

Competitive advantage has the same meaning with competitive advantage. According to Kotler competitive advantage (2001,p. 95), is a competitive over competitors gained through conveying greater customer value, through cheaper price or providing more benefits that appropriate to higher pricing.

According to Tangkilisan (2003) Competitive advantage refers to organization's ability to formulate the strategy that put in a favorable position associated with other company. Competitive advantage arises when customers feel that they receive more value from transactions made with a competing organization. In Bahasa Indonesia dictionary by Zain (1994) stated that competitive advantage are competitive.

Day \& Wensley (1998) suggested that increasing the high ability of sources which produce low costs and increase value for customers, this is controlling the position of excellence, In addition it is also said to achieve competitive advantage, companies or organizations must be able to recognize various basic elements to achieve competitive advantage as follows:

a. Price or value

b. Pleasing the consumers

c. Consumer experience

d. The product attributes that is obtained are recorded

e. Unique service privileges

Competitive advantage develops from the value that is able to be created for customer exceeds the company's costs in creating it. Competitive advantage comes from many different activities carried out by companies in designing, producing, marketing, delivering and supporting their products. Each activity can support the relative cost position and create differentiation.

Efforts to build competitive advantage

Efforts to build competitive advantage according to Chairman Lee must improve infrastructure of organization/school, improving the technology used and increasing human resources who have special talents (Song \& Lee, 2015, p. 82). Lanny Juniarti in Tandjung dkk (2016, P. 154) also express that in building of competitive 
advantage needs adequate technology and superior resource.

Then Chairman Lee in managing Samsung management become superior company which has competitive advantage and global competitiveness applies management paradox that is management pattern which applies opposite elements or factors that are applied simultaneously such as differentiation and leadership at low cost. Beside that company or organization have to build strategies that are unique in their valuable potential and involve activities that are different from those developed by competitors.

As for bulding competitive advantage of Hermawan Kertajaya version, the headmaster (principle) must develop grand design contained in the nine core elements of marketing (nine marketing elements) namely: (1) Market Segmentation (2) targeting, (3) positioning, (4) differentiation, (5) marketing mix (produk, price, place, promotion) (6) selling. (7) brand, (8) service, dan (9) process. Then Hermawan Kertajaya creates nine marketing elements are a strategy to build competitive advantage of a brand and corporation. In the nine marketing elements are made core strategy of competitive advantage building include positioning, differentiation, and brand. Every successful product or brand has succeeded in gaining a unique and strong position in the minds of consumers, because the process of determining positioning becomes a fundamental part of any marketing strategy. Because the success of something is influenced by the strength of its positioning.

In order to obtain competitive advantage must be supported by strong infrastructure. Superior human resource and technology that be used are more sophisticated than other organizations. Viewed the side of human resource infrastructure according to Emma-Sue Prince (2013) states that in achieving the success and superior human resources need to fulfill 7 potentials, these are (1) adaptation ability (2) critical thinking (3) Empathy (4) integrity (5) optimistic (6) proactive and (7) toughness.

According to Frinces (2011,p.85) there are many aspects that can encourage competitive advantage, (1) Management and leadership (2) planning (3) Human resource entrepreneurships (4) technology 5) Porter's model (6) proper strategy and organizational restructuring (7) Innovative change (8) condusive local condition (9) Strategic alliance (10) Right time (11) Innovation process.

Meanwhile, according to Barney and Wright (1998) there are four conditions that must be fulfilled before a resource can be called as a source of sustainable competitive advantage: 1) Is a valuable corporate resource, especially in relation to the ability for taking advantage of opportunities and / or neutralize threats from the corporate environment. 2) Relatively difficult to develop, so as become the step in competitive environment. 3) Difficult to be imitated or emulated. 4) Cannot be changed/substituted easily by other significant product.

\section{RESEARCH METHODOLOGY}

This research uses qualitative method which learn about existing problems to obtain an information regarding existing situations. In the reality, researcher determine research approaches that used in order to solve research problem, it is strengthen by Denscombe's opinion (2007, p. 3) that "In practice, the social is faced with a variety of options and alternatives and has to make strategic decision aboout which to shoose". That proper research approaches finally will guide researcher to start the research correctly.

Types of research that used in this research is case study. Case study is selected in this research because it is one of qualitative research which can be used especially for theory developing that raised from several research setting.

The Object of research is principal's competence in building competitive advantage at SMKM 7 Gondanglegi Malang. Including competence of personality managerial, Entrepreneurship, Supervision, social principal in building a school's competitive advantage.

This research is conducted at vocational school. As for object research is SMKM 7 Gondanglegi Malang which is located at J1. KH. Ahmad dahlan 20 Gondanglegi Malang District. The reason researcher are interested to conduct at this place because in the midst of the rise of vocational schools and the proliferation of vocational schools that are standing in Malang district. SMKM can be excellent among community, in addition many achievements that have been achieved both academic and non-academic achievements, a very prominent change in SMKM so that they are able to compete with public and private vocational school in Malang regency, even able to create competitive advantage which become the attractiveness of society to encourage their children at those vocational schools.

The data that used in this research is primary data and secondary data. Primary data is the data which obtained directly from informants and direct observation at research location about headmaster's competence in building competitive advantage at SMKM 7 Gondanglegi Malang. While secondary data is processed data in the form of written scripts/document, in this research secondary data is needed, because secondary data in the form of syllabus, 
lesson plans (RPP), and other documents relating to the competency of principals in building competitive advantage in SMK 7 Gondanglegi Malang.

Collecting data method in this research uses three collecting data techniques, these are participant observation, deep interview, and study of documents. For the analyzing data technique in this research, mainly:
a. Data condensation
b. Data display,
c. Conclusion drawing/verification

According to Miles \& Huberman (1992) the collected data must be tested using the criteria of credibility, transferability, dependability and confirmation which are intended to guarantee its validity.

1. Credibility
a. Prolonged engagement
b. Persistent observation
c. Triangulation
d. Peer debriefing
e. Referential adequacy cheks
f. Member checks

2. Transferability

3. Dependability

4. Confirmability

\section{RESULTS AND DISCUSSION}

Referring to competence of principle's personality based on Permendiknas No 13 of 2007 there are 6 Indicators, namely:

1. Having good morals, developing culture and traditions of noble morals, and being role model of noble morals for the community in schools / madrasah.

2. Having strong personality integrity as a leader

3. Having strong willingness in self developing as principle school/madrasah.

4. Be open in carrying out the principal and functions.

5. Self-controlling in encountering the problem in a job as principle school/madrasah

6. Having the talent and interest in the position as an educational leader

The headmaster of SMKM 7 Gondanglegi already has 6 indicators of that personality competence. The research data shows that there are additional indicators of his integrity as a leader who is committed to the Muhammadiyah organization for the development of a missionary education institution guided by the
Muhammadiyah foundation in order to become an institution of national pride.

One of the competencies that must be possessed by a school principal in building competitive advantage in SMK 7 Gondanglegi Malang Regency is personality competence, because one of principle's role is become a leader. As explained by Hadiyanto (2004, p. 55) as follows, the headmaster is a leader in school education level and the main spearhead who manage the education at school level. The principle school hold on the most essential role (privotal role) for school success therefore the principle school should have ability to lead a professional in managing school.

Judge and Bono in their research entitled "five-factor models of personality and transformational leadership "Someone's personality can be formed by habits, environment and education factors. Therefore, someone's personality is not formed by themselves. Clearly, personality factor is needed by everyone including the principle school can be formed through personality coaching, even though someone's personality are formed slowly from childhood to adulthood.

Without leaders who master personality competencies, a school principal will find difficulties to carry out his task of directing, fostering, and empowering existing resources to improve the quality of educational services in his school. Yet to get around and look for solutions in overcoming the problem of education such as the problem of the low quality of education services is the duty of a school principal as an education leader. It is not impossible that the problem of low quality education services can be caused by incorrect leadership caused by low personality density. (Mar'at, 1982)

Competency is a part of personality and behavior which deeply attached to someone. Competency can be used to predict someone's performance, it means if they have high competence, it should have high performance too (Napituphulu, 2017). There is no other ability in carrying out management functions such as planning, organizing, mobilizing, supervising, and evaluating all components in the school such as curriculum, personnel, students, infrastructure, finance, and environment. With that ability the headmaster will able to organize and manage the education directionally that become his responsibility, so that excellent education service can be created.

\section{CONCLUSION}

Based on research focus and exposure of result research 
about headmaster's competence in building competitive advantage at vocational school, the managerial competence of headmaster in building school competitive advantage can be carried out through these things : 1) Noble Morals, developing culture and traditions of noble morals and being good role model for community at the school/madrasah 2) Having strong personal integrity as the leader 3) Having strong willingness in self-developing as principle school/madrasah 4) Be open in doing a job as principle school/headmaster 5) Self-Controlling in dealing the problem in a job as principle school/headmaster 6) Has the talent and interest in the position as an educational leader, 7) Has a high spirit and a visionary and futuristic personality in an effort to build competitive advantage. As well as mastery of school principals on personality competencies that have a commitment to the Muhammadiyah organization for the development of educational institutions under the auspices of the Muhammadiyah foundation to become an institution of national pride.

\section{REFERENCES}

[1] Abuze, C. N. \& Ememe. (2009). Posited That O Succed In Business Behavioral Skills Such As Ability To Think Critically; Communicate Well And Work.

[2] Adams, et all. (2012). Leadership, Motivation, and Teamwork Behaviors of Principal Investigator's in Interdisciplinary Teams: A Synthesis of Research. Journal of Leadership Education, 11 (2).

[3] Akhyak, et al, (2018) Proceedings of the 5th International Conference on Community Development (AMCA 2018) hal 699. Atlantis Press.

[4] Akyak, et.al, (2013), International Journal of Education and ResearchVol. 1 No. Publisednby contemporary research center CRC publicatios Australian

[5] Akhyak, et al, (2014). American Research Institute for Policy Development.

[6] All Rights Reserved. 3942 Tulane Avenue, Madison, WI 53714, United States.

[7] Allport, G.W. (1961). Pattern and growth in personality. New York: Holt, Rinehart \& Winston.

[8] Apgar, J.M., Argumedo, A., \& Allen, W, (2009), Building transdisciplinarity for manging complexity lessons from indigenous practice. International Journal of interdisciplinary social sciences, 4 (5), 255-270.

[9] Arikunto, (1998), Prosedur Penelitian suatu pendekatan Praktek, Jakarta: PT. RinekaCipta.

[10] Argyris ,(1985), Strategy change and defensive Rountines, Boston, Pitman.

[11] Argyle, M. (1994) The Psychology of Interpersonal Behavior, 5th edition. London:Penguin Books.

[12] Bennis, W, Nanus, B, (1997), Leaders the strategies for taxing change, New york: Oxford university Press.
[13] Bogdan, R.C \& Biklen. S.K.B. ,(1998), Qualitative Research for Education to theory and Methods, Allyin and Bacon, inc. Boston.

[14] Bogdan, R.C. \& Biklen, (1992), Qualitative research for education to theory and methods, Boston: Allyn \& Bacon.

[15] Bogdan, R.C dan Biklen, S.K. (1982), Qualitative Research for Education: An Introduction to theory and Mehtods, Boston: Allyn and Bacon, Inc.

[16] Bunnel, Tim, (2004), Malaysia, Modernity and the Multimedia Super Corridor, a critical geography of intelligent lanscapes, New York: Routledgecurzon.

[17] Boulter et.al, ( 1996), people and competencies, Bidlles ltd, London.

[18] Creswell, John W, (2008), Educational Reseach, Planing, Conducting, and Evaluating Qualitative \& Qualitative Approches.London, sage

[19] Denzin, Norman K. \& Yvonna S Lincoln, (1994), Introduction Entering the field of qualitative Research, PP 1-17, thausand Oaks, CA,SAGE.

[20] Eyal \&Roth ,(2010), Principals' leadership and teachers' motivation Self-determination theory analysis. Journal of Educational Administration. Vol. 49 No. 3, 2011

[21] Fred, Luthans, (2003), Organization behavior. Alih bahasa Nurdin Sobali, Erlangga Jakarta.

[22] Glickman, et al,( 2007), Supervision and Instructional Leadership: A Developmental Approach, Boston: Allyn Bacon.

[23] Guba, E.G \& Lincoln, Y.S. (1985) Naturalistic Inquiry Baverly Hills, CA:Sage

[24] Hisrich, \& Peters,,(2002), Entrepreneurship. Fifth Edistion. New York: McGraw Hill Irwin

[25] Kotter, John P, (1996), Leading Change, Buston, Boston massachusetts, Harvard Business Pres

[26] Kristofiakova at all (2016),Improving the Quality of Technical and Vocational Education in Slovakia for European Labour Market Needs.Journal, iJEP

[27] Lee, M,J, W. Song and Lee,(2015), Habitat Mapping of the Leopard cat ( Prionailurus bengalensis) in south korea using GIS. Sustainability 7: 4668-4688.

[28] Max-Neef, M.A,(2005), Foundations of transdisciplinary. Journal Ecological Economics, 53 (1), 5-16.

[29] Mark, Brundrett. (2002). Achieving competence, success and exellence in teaching. The Scientific World Journal p. 7

[30] Milles., Hubermen., \& Saldana ,(2014), Qualitative data analysis: A methodssourcebook and the coding manual for qualitative researchers. Arizona: sagr Group.

[31] Mintzberg, Henry, et al, (1998), Strategy safary A Guided tour Thraught the wilds of strategic management. Jounal Revolusi, 2 (8), 20.

[32] Nordahl, R., \& Serafin, S, (2008), Using problem bsed learning to support transdisciplinarity in an HCL education. Interaction Design and Architecture (s) Journal, 6 (3), 94101.

[33] Olson and bolton, (2001), Charakterize Collective action at the organizational level, According to a reportn,Journal leadership of education. 
International Journal of English Literature and Social Sciences, 5(5)

Sep-Oct 2020 | Available online: $\underline{\text { https://ijels.com/ }}$

[34] Palan. R, (2007), Competency Manajement PPM. Jakarta: Salemba Empar,

[35] Park (2017), Soft skills in health careers programs: a case study of a regional vocational technical high school.Theses \& Dissertations Boston University Theses

[36] Phillip.K, dkk. (2017), Marketing for Competitifness, Yogyakarta, Bentang Pustaka.

[37] Roe, Robert A, (2001), Pengertian Kompetensi. (online). Tersedia http;//www.dostoc.com/does/2656466/ pengertian kompetensi, (19 April 2009)

[38] Rusmiwari Sugeng dkk, (2012), Model Kepemimpinan Visioner dan Integratifdalam Meningkatkan Kompetensi Kepemimpinan, Jurnal Reformasi, 2 (1), 20.

[39] Sallis, E , (2002), Total Quality Management in Education. London: Kagan Page

[40] Sallis, E , (1994),Total Quality Managemen in Education. London: Kagan Page 